\title{
Thoughts on the Teaching Reform of Economic Law Courses for Economic Management Majors
}

\author{
Yuanzhao Zhang* \\ Lanzhou Resources\&Environment Voc-Tech College, Lanzhou 730021, Gansu, China. \\ E-mail: zyz-1986@163.com
}

\begin{abstract}
With the continuous progress and development of the global economy, the teaching quality of economic law courses in economics and management in colleges and universities has also received close attention. Colleges and universities, as the transportation base of professional and applied high-quality talents, not only Real-time innovative teaching strategies are needed to improve the actual effects of classroom teaching, and more scientific and reasonable teaching goals must be formulated according to the development situation of the modern social market economy, and more targeted to cultivate talents with high literacy in line with the development of modern society to meet the economic development needs of modern society as much as possible.
\end{abstract}

Keywords: Economics and Management; Economic Law; Teaching; Reform

In recent years, the Ministry of Education of China has paid more and more attention to the quality construction and development of higher education. As far as economic law is concerned, it is not only a basic course for economics and management, but also an important component of the entire economics and management professional curriculum system $^{[1]}$. In the selection and formulation of relevant course content and teaching tasks, colleges and universities should appropriately combine the requirements of the legal field related to economic knowledge, adopt teaching strategies that are more in line with the socialist legal system, and effectively strengthen the accumulation of students' basic legal knowledge. So as to improve students' comprehensive application ability of laws and regulations more quickly. Based on the basic problems existing in the economic law course teaching of economics and management majors at this stage, combined with the practical significance of the economic law course teaching reform, this article proposes several reasonable reform application methods, and gives a simple explanation for reference.

\section{Basic problems existing in the teaching of economic law courses for economics and management majors at this stage}

Judging from the current situation of economic law teaching in colleges and universities, the actual teaching effect is not obvious. On the one hand, the teaching mode of teachers is relatively traditional and single, and they have not kept up with the new era economy in real time. To improve and innovate teaching methods, the teaching quality of economic law courses cannot meet the actual learning needs of college students. On the other hand, the teaching concepts of teachers are still at a relatively backward stage. In daily course teaching, students are ignored as the main body of teaching, and teachers are still occupying the actual dominant position, which to a certain extent is quite unfavorable for students' comprehensive ability training.

In addition, teachers lack a certain degree of pertinence in the setting of curriculum content and the formulation of teaching tasks. When most teachers develop basic teaching of economic law, they ignore the importance of the practical part, and often only focus on students' mastery and accumulation of theoretical knowledge, so that it is difficult for stu-

Copyright (C) 2020 Yuanzhao Zhang

doi: $10.18282 /$ le.v9i6.1288

This is an open-access article distributed under the terms of the Creative Commons Attribution Non-Commercial License

(http://creativecommons.org/licenses/by-nc/4.0/), which permits unrestricted non-commercial use, distribution, and reproduction in any medium, provided the original work is properly cited. 
dents to effectively transform professional theoretical knowledge, nor can they use it accurately in real life. Due to the lack of certain practical training, students cannot carry out relevant regulations on economic law. A deeper understanding and digestion is also the main reason for the relatively low learning efficiency of the students' economic law professional knowledge.

\section{The practical significance of the teaching reform of economic law courses in economics and management majors}

The essential purpose of reforming and innovating the economic law teaching mode of economics and management majors is to cultivate practical and application-oriented talents for society ${ }^{[2]}$. Therefore, if colleges and universities want to implement this teaching goal on a practical level, it is an inevitable trend to implement innovative teaching of economic law courses. Teachers can not only improve the quality and efficiency of classroom teaching more effectively, but also combine the actual learning needs of students, and give full play to the students' role of the main body, to truly teach students in accordance with their aptitude, which can greatly stimulate students' interest and enthusiasm for learning, and also enables students to actively participate in the learning of professional knowledge of economic law, and more comprehensively strengthen students' understanding of economics. The understanding and accumulation of law theory knowledge, and at the same time, with the organic combination of practice and theory, teachers can more quickly extend and expand the theoretical knowledge of economic law, so as to effectively promote students' practical ability and professionalism. While students' application ability being further cultivated, it can also improve the students' legal awareness and legal thinking in a targeted manner, so as to promote the strengthening and improvement of the actual effect of teaching more quickly.

\section{The application path of economic law course teaching reform for economic management majors}

\subsection{Interactive teaching stimulates interest in learning}

In terms of the actual effects of economic law teaching in economics and management majors at this stage, there is still greater room for improvement in students' mastery of basic legal knowledge. Therefore, teachers must not only update teaching concepts in a timely manner, continuously improve teaching methods, and effectively improve the quality and efficiency of economic law curriculum knowledge, but also be able to develop more targeted courses based on students' understanding of economic law knowledge to strengthen students' legal awareness and the cultivation of legal thinking. As the professionalism of economic law is relatively stronger, teachers begin to pay attention to the effective penetration of legal knowledge in the economic field and related professional terminology during the course of teaching economic law courses, so that students can learn about economic law in real time. The accumulation of basic knowledge will gradually help students expand their awareness of legal awareness.

In addition, teachers can also conduct interactive questions and answers in the classroom based on the basic knowledge related to real life, stimulate students' interest in learning, effectively grasp the attention of students in the classroom, and create a more relaxed and harmonious learning atmosphere. In order to better help students deepen their understanding and consolidation of knowledge of economic law, teachers can also conduct appropriate in-depth discussions and knowledge extension with students according to the actual learning effects of students to help students further strengthen abilities to apply knowledge of economic law. This not only can effectively improve the students' mastery of economic and legal knowledge, but also promotes students to develop better learning habits in real time, and more actively participate in the learning of economic law courses.

\subsection{Blended teaching to strengthen knowledge accumulation}

First of all, teachers should pay a high degree of attention to the current economic development situation, appropriately abandon the traditional passive indoctrination teaching mode, and adopt more diversified teaching strategies, so as to more comprehensively strengthen the cultivation of students' innovative comprehensive ability. This is also extremely important for the future development of students. Therefore, when teachers develop courses of economic law 
knowledge, they should formulate a more systematic and scientific teaching model based on the actual learning situation of the students, and pay more attention to cultivating students' legal thinking. Teachers can combine the current Conduct interactive discussions with students on economic hot issues, appropriately develop students' legal awareness in the economic field, and provide real-time guidance to students with insufficient cognition so that students can accurately recognize their own problems and give them advice. Adjustments and improvements can effectively improve the students' development ability, so that when students encounter similar economic and legal problems, they can use relevant laws and regulations to deal with them rationally and improve their practical application ability.

Secondly, the development of information network technology in modern society is becoming more and more mature. Teachers can appropriately use online high-quality learning platforms to develop online and offline teaching methods ${ }^{[1]}$, and they can make targeted choices that are more in line with the modern high-quality teaching resources for social and economic development, to build a more complete economic law curriculum system. Students can also consolidate relevant economic law theoretical knowledge more comprehensively through online methods, accumulate and supplement them anytime and anywhere, and strengthen their understanding and mastery of economic law knowledge in real time.

\subsection{Case practice teaching to improve application ability}

For the economic law subjects of economics and management majors, the curriculum features not only strengthen the accumulation and transformation of theoretical knowledge, but also the practical ability of students is one of the focuses of the inspection. Therefore, teachers can appropriately combine relevant actual cases when teaching economic law courses, so as to more quickly achieve the purpose of strengthening the students' analytical and judgment ability. The students' analysis and handling of actual cases can effectively reflect the students' comprehensive application ability, and more comprehensively improve the quality and efficiency of economic law classroom teaching. Secondly, through the discussion and analysis of actual cases, teachers can summarize and expand the important and difficult points in the knowledge of economic law courses in a targeted manner, and deepen students' impression of the theoretical knowledge of economic law, so as to facilitate students to understand and master key and difficult knowledge.

On the other hand, teachers should appropriately create case scenarios and give students an appropriate time for independent thinking. After class, they can reserve classic social current affairs cases so that students can find relevant economic laws and regulations to make a comprehensive analysis of the cases. The analysis, combined with the professional knowledge of the courses learned to solve the problem, essentially improve the students' practical application ability, truly apply what they have learned, and achieve the learning effect of analogy, thereby helping students to shape more correct laws concepts ${ }^{[3]}$.

In summary, economic law, as one of the core courses of economics and management majors today, is a subject that is equally critical in theory and practice, and the practical application of economic law is relatively strong. Therefore, in order to better meet the actual learning needs of students at this stage in the process of paying attention to knowledge transfer, colleges and universities must continue to develop more innovative teaching strategies to improve the quality of teaching courses, and complete teaching achievement goals more quickly.

\section{References}

1. Zhai Y. Research on the interactive mixed teaching system of economic law courses for economics and management majors.Chinese and Foreign Entrepreneurs 2019; (36): 132-134.

2. Wu X. Exploration of economic law teaching reform in economics and management majors in colleges and universities. Industry and Technology Forum 2019; 18(22): 201-202.

3. Yan H. Exploration of the teaching reform of economic law courses for economics and management majors. Journal of Guangxi Institute of Education 2019; (05): 148-151. 